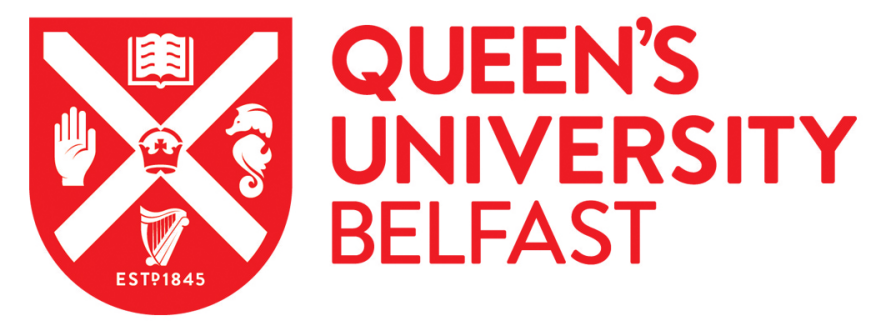

\title{
An in vitro investigation on the cytotoxic and nuclear receptor transcriptional activity of the mycotoxins fumonisin B1 and beauvericin
}

Fernández-Blanco, C., Frizzell, C., Shannon, M., Ruiz, M-J., \& Connolly, L. (2016). An in vitro investigation on the cytotoxic and nuclear receptor transcriptional activity of the mycotoxins fumonisin B1 and beauvericin. Toxicology Letters, 257, 1-10. https://doi.org/10.1016/j.toxlet.2016.05.021

Published in:

Toxicology Letters

Document Version:

Peer reviewed version

Queen's University Belfast - Research Portal:

Link to publication record in Queen's University Belfast Research Portal

Publisher rights

(C) 2016 Elsevier

This is an open access article published under a Creative Commons Attribution-NonCommercial-NoDerivs License

(https://creativecommons.org/licenses/by-nc-nd/4.0/), which permits distribution and reproduction for non-commercial purposes, provided the author and source are cited.

\section{General rights}

Copyright for the publications made accessible via the Queen's University Belfast Research Portal is retained by the author(s) and / or other copyright owners and it is a condition of accessing these publications that users recognise and abide by the legal requirements associated with these rights.

Take down policy

The Research Portal is Queen's institutional repository that provides access to Queen's research output. Every effort has been made to ensure that content in the Research Portal does not infringe any person's rights, or applicable UK laws. If you discover content in the Research Portal that you believe breaches copyright or violates any law, please contact openaccess@qub.ac.uk. 
1 An in vitro investigation on the cytotoxic and nuclear receptor transcriptional 2 activity of the mycotoxins fumonisin $\mathrm{B} 1$ and beauvericin.

3 Celia Fernández-Blanco ${ }^{1}$, Caroline Frizzell ${ }^{2}$, Maeve Shannon ${ }^{2}$, Maria-Jose Ruiz ${ }^{1}$, Lisa Connolly $^{2} *$.

Laboratory of Toxicology, Faculty of Pharmacy, University of Valencia, Av. Vicent Andrés Estellés s/n, 46100 Burjassot, Valencia, Spain. Institute for Global Food Security, School of Biological Sciences, Queen's University, Belfast, Northern Ireland, United Kingdom.

\section{Abstract}

Fumonisin B1 (FB1) and beauvericin (BEA) are secondary metabolites of filamentous fungi, which under appropriate temperature and humidity conditions may develop on various foods and feeds. To date few studies have been performed to evaluate the toxicological and endocrine disrupting effects of FB1 and BEA. The present study makes use of various in vitro bioassays including; oestrogen, androgen, progestagen and glucocorticoid reporter gene assays (RGAs) for the study of nuclear receptor transcriptional activity, the thiazolyl blue tetrazolium bromide (MTT) assay to monitor cytotoxicity and high content analysis (HCA) for the detection of pre-lethal toxicity in the RGA and Caco-2 human colon adenocarcinoma cells.

At the receptor level, 0.001-10 $\mu \mathrm{M}$ BEA or FB1 did not induce any agonist responses in the RGAs. However at non-cytotoxic concentrations, an antagonistic effect was exhibited by $\mathrm{FB} 1$ on the androgen nuclear receptor transcriptional activity at $10 \mu \mathrm{M}$ and BEA on the progestagen and glucocorticoid receptors at $1 \mu \mathrm{M}$. MTT analysis showed no decrease in cell viability at any concentration of FB1, whereas BEA showed a significant decrease in viability at $10 \mu \mathrm{M}$. HCA analysis confirmed that the reduction in the progestagen receptor transcriptional activity at $1 \mu \mathrm{M}$ BEA was not due to pre-lethal toxicity. In addition, BEA $(10 \mu \mathrm{M})$ induced significant toxicity in both the TM-Luc (progestagen responsive) and Caco-2 cells.

Keywords: Mycotoxin, Beauvericin, Fumonisin B1, Reporter gene assay, High Content Analysis.

* Corresponding author: Tel.: +44 28 90976668; fax: +44 28 90976513. E-mail address: 1.connolly@qub.ac.uk (L. Connolly). 


\section{Introduction}

Mycotoxins are secondary metabolites of filamentous fungi, which under appropriate temperature and humidity conditions may develop on various foods and feeds. They are mainly produced by fungi belonging to the genera Aspergillus, Penicillium, Fusarium, Alternaria and Claviceps (Fung et al., 2004). Fusarium species are contaminants of wheat, maize, and other grains worldwide, capable of producing high levels of fumonisin mycotoxins. Fumonisin B1 (FB1) is the most prevalent of the fumonisins, accounting for approximately $70 \%$ of total fumonisins (Martins et al., 2012). Studies have also highlighted that Fusarium species can co-produce other mycotoxins such as Beauvericin (BEA) simultaneously (Dombrink-Kurtzman, 2003).

Total fumonisin concentrations in feed materials have been reported to vary from a few $\mu \mathrm{g} / \mathrm{kg}$ to tens of $\mathrm{mg} / \mathrm{kg}$ (EFSA, 2005). Dietary fumonisin estimates, by the Food and Agriculture Organization of the United Nations and World Health Organization (FAO/WHO, 2001), indicate exposure levels ranging from $0.02-0.2 \mu \mathrm{g} / \mathrm{kg}$ in body weight (b.w.)/day, thus remaining below the Tolerable Daily Intake (TDI) of $2 \mu \mathrm{g} / \mathrm{kg}$ b.w./day as set in Europe by the Scientific Committee on Food (SCF, 2003). Nevertheless, a wide range of animal diseases and pathophysiological effects such as leukoencephalomalacia, porcine pulmonary oedema, liver and kidney toxicity and liver cancer, as well as human oesophageal carcinoma are associated with FB1 ingestion (Harrison et al., 1990; Kellerman et al., 1990; Gelderblom et al., 1997; Hussein et al., 2001). While the molecular mechanism of FB1 toxicity is poorly understood, it appears to be related to the deregulation of sphingolipid metabolism (Merrill et al., 2001).

BEA is predominantly found in cereal grains such as wheat, maize and rice (Serrano et al., 2012) as well as other matrices such as nuts and dried fruits (Tolosa et al., 2013). The mean dietary exposure to BEA varies from a minimum of $0.003 \mu \mathrm{g} / \mathrm{kg}$ b.w./day to a maximum of $0.050 \mu \mathrm{g} / \mathrm{kg}$ b.w./day (EFSA, 2014). However, the Panel on Contaminants in the Food Chain (CONTAM) concluded that there was insufficient data to establish a TDI or/and an acute reference dose (ARfD) for BEA in humans (EFSA, 2014). BEA possesses a wide range of biological activities. These substances are known as ionophores, forming a complex with essential cations $(\mathrm{Ca} 2+, \mathrm{Na}+, \mathrm{K}+)$, which increases ion permeability of biological membranes, therefore potentially affecting ionic homeostasis (Chen et al., 2006). Many mycotoxins such as ochratoxin A, patulin, alternariol and zearalenone have been found to possess endocrine disrupting capabilities (Frizzell et al., 2011, 2013a, 2013b and 2014). 

may interfere with the body's endocrine system by acting like endogenous hormones and inducing adverse developmental, reproductive, neurological and immune effects (IPCS, 2002). A few studies suggest that FB1 may act as a potential ED (Collins et al., 1998; Gbore et al., 2009). While there is not enough data to confirm that FB1 is a developmental or reproductive toxicant in animals or humans, Collins et al., (1998) reported that FB1 was toxic to maternal rats and the foetus at $15 \mathrm{mg} / \mathrm{kg}$ of feed consumption. In addition, Gbore (2009) reported that FB1 affected fertility in pigs by causing a delay in sexual maturity and poor sperm production and quality. There are no in vivo toxicological studies available on reproduction and developmental toxicity, neurotoxicity or carcinogenicity for BEA. However, it has been shown to be absorbed and rapidly metabolised to a range of uncharacterised metabolites as detected in the eggs of laying hens and several tissues of turkeys and broilers (Jestoi, 2008).

In vitro bioassays may be used to investigate the toxicity and endocrine disrupting potential of compounds (Connolly et al., 2011). The emerging technology, High Content Analysis (HCA) is a highly powerful multi-parameter bio-analytical based tool incorporating fluorescent microscopy with automated in vitro cell analysis software. HCA provides assays with high sensitivity and specificity for pre-lethal cytotoxicity and multiple biological endpoints for use as a high throughput-screening tool to monitor the cytotoxicity, endocrine disruption and biological effects of compounds on exposed cells (Clarke et al., 2015).

In this study, we have investigated the endocrine disrupting and cytotoxic potential of FB1 and BEA using various in vitro bioassays. Reporter gene assays (RGAs) utilising human mammary gland cells with natural steroid hormone receptors for oestrogens, androgens, progestagens and glucocorticoids (Willemsen et al., 2004) are employed for the identification of endocrine disruption at the level of nuclear receptor transcriptional activity. HCA is used to detect early cytotoxicity, via multiple markers in the progestagen responsive (TM-Luc) cell line exposed to 0.001-10 $\mu \mathrm{M}$ BEA, to ensure that a reduction in transcriptional activation of endocrine receptors is not correlated with pre-lethal toxicity. HCA is also used to assess cytotoxicity in colon adenocarcinoma (Caco-2) cells because the ingestion of food contaminated with FB1 and BEA is the main exposure route for animals and humans. 


\section{Materials and methods}

\subsection{Reagents}

Methanol, thiazolyl blue tetrazolium bromide (MTT), FB1, BEA and the steroid hormones $17 \beta$-estradiol, testosterone, progesterone and hydrocortisone were obtained from Sigma-Aldrich (Poole, Dorset, UK). Cell culture reagents were obtained from Life Technologies (Paisley, UK). Multiparameter cytotoxicity 2 multiplex kit (8400202) containing mitochondrial probe and cell membrane permeability dye was supplied by Thermo Scientific, UK. Stock solutions of FB1 and BEA were prepared in methanol and stored at $-20^{\circ} \mathrm{C}$. FB1 and BEA were dissolved in methanol at a final concentration of $0.5 \%(\mathrm{v} / \mathrm{v})$ in media for the RGAs, MTT assays and HCA.

\subsection{Cell culture}

All cells were routinely cultured in $75 \mathrm{~cm} 2$ tissue culture flasks (Nunc, Roskilde, Denmark) at $37^{\circ}$ with $5 \% \mathrm{CO}_{2}$ and $95 \%$ humidity.

Four RGA cell lines were previously developed by the transformation of human mammary gland cells with the luciferase gene under the control of a steroid hormone inducible promoter (Willemsen et al., 2004). The MMV-Luc cell is specific for the detection of oestrogens, TARM-Luc for androgens and progestagens, TM-Luc for progestagens and TGRM-Luc for glucocorticoids and progestagens. The RGA cells were routinely grown in cell culture medium containing Dulbecco's Modified Eagle Medium (DMEM), 10\% foetal bovine serum (FBS) and 1\% penicillin streptomycin. As phenol red is a weak oestrogen, DMEM without phenol red was used when culturing the MMV-Luc cells. Cells were transferred prior to RGA analysis into assay media, which was composed of DMEM and 10\% hormone depleted serum.

The Caco-2 cell line (ATCC HTB-37) was routinely grown in DMEM medium, $10 \%$ FBS and $1 \%$ penicillin streptomycin.

\subsection{Reporter gene assay (RGA).}

RGAs were carried out as previously described by Frizzell et al. (2011). Briefly, cells were seeded at a concentration of $4 \times 10^{5}$ cells $/ \mathrm{ml}, 100 \mu \mathrm{l} /$ well, into white walled 96 well plates with clear flat bottoms (Greiner Bio-One, Germany). The cells were incubated for $24 \mathrm{~h}$ and then exposed to BEA and FB1 $(0.001,0.01,0.1,1,10 \mu \mathrm{M})$ for the agonist test. The positive control used with each cell line was as follows: $1.35 \mathrm{ng} / \mathrm{ml}$ $17 \beta$-estradiol (MMV-Luc cells), $14.5 \mathrm{ng} / \mathrm{ml}$ testosterone (TARM-Luc cells), $157 \mathrm{ng} / \mathrm{ml}$ 
progesterone (TM-Luc cells) and $181 \mathrm{ng} / \mathrm{ml}$ hydrocortisone (TGRM-Luc cells). A solvent control $0.5 \%(\mathrm{v} / \mathrm{v})$ methanol in media was also added to each plate. Antagonist tests were carried out by incubating BEA and FB1 $(0.001,0.01,0.1,1,10 \mu \mathrm{M})$ with the relevant positive control for each cell line. The cells were incubated for $48 \mathrm{~h}$, after which, the media was discarded and the cells washed once with phosphate buffered saline (PBS). The cells were lysed with $30 \mu \mathrm{l}$ cell culture lysis buffer (Promega, Southampton, UK) and then $100 \mu$ luciferase (Promega, Southampton, UK) injected into each well and the response measured using the Mithras Multimode Reader (Berthold, Other, Germany). The response of the cells to the various compounds was measured and compared with the solvent control.

\subsection{Cell viability assay}

\subsection{HCA multi-parameter assay}

HCA is a rapid and robust technology which can determine multiple cytotoxic effects, including early (pre-lethal) as well as late-stage occurrences of cytotoxicity simultaneously. The cytotoxicity of BEA and FB1 was assessed on Caco-2 cells as an effective indicator of toxicity to the human gut. The TM-Luc cell line was also investigated by HCA to confirm whether pre-lethal toxicity was inducing the antagonist response observed at $1 \mu \mathrm{M}$. 
Briefly, cells were seeded at a concentration of $2 \times 10^{4}$ cells $/ \mathrm{ml}, 100 \mu \mathrm{l} /$ well, into 96 well plates (Nunc, Roskilde, Denmark). The cells were incubated for $24 \mathrm{~h}$ and then exposed to $(0.001,0.01,0.1,1,10 \mu \mathrm{M})$ of BEA (TM-Luc cells for $48 \mathrm{~h}$ ) and BEA or FB1 (Caco-2 cells for 24 and $48 \mathrm{~h}$ ).

Cellomics® HCA reagent series multi-parameter cytotoxicity dyes were utilised. Mitochondrial membrane potential dye was prepared by adding $117 \mu$ l of anhydrous DMSO to make a $1 \mathrm{mM}$ stock. Permeability dye was used as provided in the multiparameter cytotoxicity 2 multiplex kit (8400202). The live cell staining solution was prepared by adding $2.1 \mu \mathrm{l}$ permeability dye to $6 \mathrm{ml}$ of complete media that had been preheated to $37^{\circ} \mathrm{C}$, and then $21 \mu \mathrm{l}$ of mitochondrial membrane potential (final concentration $3.5 \mathrm{mM}$ ). Nuclear stain solution was prepared by adding $5.5 \mu \mathrm{l}$ Hoechst 33342 dye to $11 \mathrm{ml} 1 \mathrm{X}$ Wash Buffer.

After incubation, $50 \mu \mathrm{l}$ of live cell staining solution was added to each well. Cells were incubated in the dark at $37^{\circ} \mathrm{C}$ and $5 \% \mathrm{CO}_{2}$ for $30 \mathrm{~min}$. The staining solution was aspirated and $100 \mu \mathrm{l}$ of $10 \%$ formalin solution (fixation solution) added. The cells were incubated for $20 \mathrm{~min}$ at room temperature before discarding the fixation solution and washing the cells with $100 \mu \mathrm{l}$ of PBS. Nuclear staining solution $(100 \mu \mathrm{l})$ was then added, and the cells incubated for $10 \mathrm{~min}$ at room temperature protected from light. The cells were then washed twice and the wells filled with $100 \mu \mathrm{l}$ of PBS. Cell number $(\mathrm{CN})$, nuclear area (NA), nuclear intensity (NI), plasma membrane permeability (PMP), mitochondrial membrane potential (MMP) and mitochondrial mass (MM) were measured using the CellInsight ${ }^{\mathrm{TM}}$ NXT High Content Screening platform (Thermo Fisher Scientific, UK).

\subsection{Statistical analysis}

Assay exposures were carried out in triplicate wells and in three independent experiments. Results were expressed as the mean \pm standard error of the mean (SEM) of the triplicate exposures. For the RGAs, data was analysed using Microsoft Excel and Graphpad PRISM software (San Diego, CA). A one way analysis of variance (ANOVA) and Dunnett's multiple comparison test was used to determine significant differences between the treatments and the corresponding controls in the RGAs, MTT assays and HCA. The mean concentrations were tested for significant difference at the $95 \%$ confidence level. A $p$ value of $<0.05$ was considered statistically significant, $p=\leq$ $0.05(*), \leq 0.01(* *)$ and $\leq 0.001(* * *)$. 


\subsection{Cell viability}

202

The MTT assay was used to determine the viability of the RGA cells following exposure to FB1 or BEA $(0.001-10 \mu \mathrm{M})$. No cytotoxicity was observed in any of the RGA cell lines exposed to 0.001-10 $\mu \mathrm{M}$ FB1 (Fig.1) or 0.001-1 $\mu \mathrm{M}$ BEA. However, at $10 \mu \mathrm{M}$ BEA, a decrease in cell viability for all RGA cell lines was observed $(p \leq 0.001)$ (Fig. 1).

\subsection{Reporter gene assays}

Neither FB1 nor BEA $(0.001-10 \mu \mathrm{M})$ exhibited an agonist response in any of the four RGA cell lines (data not shown). However FB1, at the highest concentration tested $(10 \mu \mathrm{M})$, exhibited an antagonistic effect $(p \leq 0.05)$ on the androgen nuclear receptor transcriptional activity (Fig. 2b). No antagonist effects were observed in the progestagen, glucocorticoid or oestrogen RGAs (Fig. 2a, c and d). BEA, at the highest concentration tested $(10 \mu \mathrm{M})$, exhibited a strong antagonistic response $(p \leq 0.001)$ in the oestrogen, androgen, progestagen and glucocorticoid RGAs (Fig. 3a-d). However, the MTT assay results indicate that this response is due to the cytotoxicity of BEA at $10 \mu \mathrm{M}$ on all of the RGA cell lines. Antagonistic effects on nuclear receptor transcriptional activity in the progestagen $(p \leq 0.05)$ and glucocorticoid $(p \leq 0.01)$ RGAs were also observed at non-toxic concentrations of $1 \mu \mathrm{M}$ BEA (Fig. 3c and d). Considering that BEA is cytotoxic to all of the RGA cell lines at $10 \mu \mathrm{M}$, it is possible that the antagonism observed at $1 \mu \mathrm{M}$ BEA is not a true response and instead may be due to pre-lethal toxicity being initiated within the cells. The validity of this response was further explored by HCA in the progestagen responsive, TM-Luc cell line.

\subsection{High Content Analysis (HCA).}

In the TM-Luc (progestagen responsive) cell line, BEA $(10 \mu \mathrm{M})$ was not possible to analyse due to lethal cytotoxic effects. BEA $(1 \mu \mathrm{M})$ did not show any significant differences when compared to the control. Therefore, no pre-lethal toxicity was observed at $1 \mu \mathrm{M}$ BEA, confirming that the antagonism observed in the progestagen RGA was a true response (Fig. 4). 
Exposure of Caco-2 cells to $0.001-10 \mu \mathrm{M}$ FB1 or BEA revealed that $1 \mu \mathrm{M}$ BEA caused a significant $(p \leq 0.01)$ decrease in the CN (Fig. 5). Nevertheless, $10 \mu \mathrm{M}$ BEA was not possible to analyse due to lethal cytotoxic effects on the Caco-2 cells.

\section{Discussion}

The MTT assay confirmed that FB1 $(0.1-10 \mu \mathrm{M})$ was not cytotoxic to any of the four RGA cell lines. This value is consistent with other publications, Meca et al., (2010) showed that exposure of Vero cells (monkey kidney) to 0-100 $\mu \mathrm{M}$ FB1 for $24 \mathrm{~h}$ decreased cellular viability to $60 \%$ at $100 \mu \mathrm{M}$ when compared to the control. In addition, Wan et al., (2013) did not observed a reduction of viability from 0 to $20 \mu \mathrm{M}$ FB1 in IPEC-J2 (porcine jejunal epithelial) cell line after $48 \mathrm{~h}$ of exposure.

BEA reduced cell viability at a concentration of $10 \mu \mathrm{M}$ in all of the RGA and Caco- 2 cell lines. BEA $(1 \mu \mathrm{M})$ also decreased viability in the Caco- 2 cell line upon $48 \mathrm{~h}$ exposure. This data is consistent with previous studies whereby 24 and $48 \mathrm{~h} 0-30 \mu \mathrm{M}$ BEA exposure of Caco-2 cells decreased viability to $80 \%$ and $87 \%$ respectively and HT-29 (human colon adenocarcinoma) cells presented a decrease of $85 \%$ at $24 \mathrm{~h}$ and $90 \%$ at 48 h ( Prosperini et al., 2012). Similar results were obtained by Calo et al. (2004) with two human cell lines of myeloid origin (U-937 and HL-60 cells) and Ferrer et al. (2009) who investigated 0-100 $\mu \mathrm{M}$ BEA exposure on Chinese hamster ovary cells (CHO-K1). They observed a decline in viability at a concentration of $10 \mu \mathrm{M}$ or higher after $24 \mathrm{~h}$.

The application of HCA in toxicity studies is based on the parallel analysis of multiple markers for cytotoxicity, which allows early reversible and late irreversible effects to be distinguished, and thus provides a more detailed analysis of compoundinduced toxicity (Ramirez et al. 2010; Tolosa et al., 2015). In this context, HCA can identify gross toxicity and pre-lethal toxicity, whereby exposed cells are not dead but are becoming unhealthy. While traditional end-point toxicity assays such as MTT can identify gross toxicity, they cannot do so for pre-lethal toxicity.

In the current study, an antagonist response was observed in the progesterone responsive TM-Luc cell line after exposure to $1 \mu \mathrm{M}$ BEA. While the MTT assay was able to confirm cytotoxicity via BEA exposure at $10 \mu \mathrm{M}$ but not at $1 \mu \mathrm{M}$, the potential for pre-lethal toxicity being responsible for the perceived antagonist response was considered. Consequently, HCA analysis was utilised to confirm the absence of pre- 
lethal toxicity and thus confirm the validity of the progesterone receptor antagonist response.

The Caco-2 cell line is a well-recognised human gut cell model (Sambuy et al., 2004) and as such is suited to investigating the toxic effects of food contaminants. HCA analysis confirmed that FB1 was not cytotoxic at any of the concentrations tested on the Caco-2 cell line. However, BEA exhibited cytotoxicity at $1 \mu \mathrm{M}$ on the Caco-2 cell line. Furthermore, in this study was observed a slight decrease in MMP at $1 \mu \mathrm{M}$ BEA. According to Jow et al. (2004), Ca2+-dependent pathway by BEA involves cell death, in which it induced an increase in intracellular $[\mathrm{Ca} 2+]$ that leads to a combination of cellular apoptosis and necrosis responses. Moreover, Tonshin et al., (2010) in isolated mitochondria BEA induced a loss of MMP where $\mathrm{K}+$ inflow into the mitochondrial matrix and uncoupling of oxidative phosphorylation, followed by induction of apoptosis. In addition, Prosperini et al., (2013) investigated that Caco-2 cells exhibit mitochondrial dysfunction leading a stable depolarized state of MMP and cell death after exposure of 1.5 and $3 \mu \mathrm{M}$ BEA. Low BEA concentrations might be reached due to food consumption and based on tissue accumulation (Jestoi et al., 2007). Moreover, with regard to food intake, BEA might increase the absorption of commonly cooccurring mycotoxins probably leading to higher toxicity. Thus, exposure to low BEA concentrations activates diverse cellular stress response and protection systems (Mallebrera et al., 2014). This indicates that continuous exposure to BEA might lead to alter the intestinal epithelial barrier (Dornetshuber et al., 2009).

Antagonism of the androgen receptor in the TARM-Luc cell line was observed following exposure to $10 \mu \mathrm{M}$ FB1. A reduction in the transcriptional activity of the androgen, glucocorticoid, oestrogen and progestagen receptor was correlated to the cytotoxic effects of BEA at $10 \mu \mathrm{M}$ rather than true antagonism. An antagonistic response was also observed in the TGRM-Luc (glucocorticoid) and TM-Luc (progesterone) cell lines following exposure to $1 \mu \mathrm{M}$ BEA. HCA established that no pre-lethal toxicity was evident in the TM-Luc cell line at $1 \mu \mathrm{M}$ BEA and thus the reduction in progesterone receptor transcriptional activity was confirmed as a true antagonist response. To the authors' knowledge, this is the first study investigating the endocrine disrupting effects of FB1 and BEA at the level of nuclear receptor activity. The actions of progesterone, glucocorticoid and androgen are mediated by its receptor. In the target cell, progesterone, glucocorticoid and androgen produce a change in 
conformation of its receptors that is associated with transforming receptors from a nonDNA binding form to one that will bind to DNA (Spitz et al., 2003). This transformation is go with a loss of associated heat shock proteins and dimerization. The activated receptors dimers then binds to specific DNA sequences within the promotor region of progesterone, glucocorticoid and androgen responsive genes. Antagonist impair the ability of receptors to interact with coactivators allowing the recruitment of corepressors (Liu et al., 2002). The antagonist activity of an antihormone may depend on the cell or tissue type. In addition, these transformations in the structure and function of the receptor results in numerous endocrine disorders. Many antagonists of progesterone receptor display antiproliferative effects in the endometrium by suppressing follicular development and blocking the LH flood. Moreover, progesterone antagonists are potent antiglucocorticoid agents (Neulen et al., 1996). GR signalling is requiered for homeostatic control of pyramidal neurons. Thus, GR hormone influence memory, mood, and neuronal survival (Savory et al., 2001) Therefore, inhibition of the GR may affect the peripheral glucose metabolism, the stress response, and the regulation of the hypothalamic pituitary axis (Honer et al., 2003; Deroche-Gamonet et al., 2003). The regulatory steroidal sex hormones role in developmental processes such as sex determination and differentiation is of particular interest with regard to endocrine disruption (Kelce et al., 1995; 1997). Androgens, through interaction with the androgen receptor, play decisive roles in sexual differentiation of the male reproductive tract, accessory reproductive organs, and other tissues during fetal development. They also influence male pubertal maturation and the maintenance of secondary sex characteristics in adults. (Wilson et al., 2001)

This in vitro investigation has demonstrated the potential for FB1 and BEA to modulate the endocrine system by antagonism of nuclear transcriptional activity as observed for BEA $(1 \mu \mathrm{M})$ on the glucocorticoid and progesterone receptor and FB1 (10 $\mu \mathrm{M})$ on the androgen receptor. HCA has also proven to be an added value cytotoxic assessment tool in establishing pre-lethal toxicity in exposed cells and confirming antagonistic responses. In addition, while FB1 did not show any significant cytotoxic effects on mammalian gut cells, BEA did at a concentration of $1 \mu \mathrm{M}$. Further investigation is needed to investigate the risk of BEA and FB1 exposure in humans and animals. 
The authors declare that there are no conflicts of interest.

332

333 Acknowledgement

334 The authors wish to thank Rachel Clarke for her help and training the High 335 Content Analysis and to the Economy and Competitiveness Spanish Ministry 336 (AGL2013-43194-P)

337 


\section{References}

Calò, L., Fornelli, F., Ramires, R., Nenna, S., Tursi, A., Caiaffa, M.F., Macchia, L., 2004. Cytotoxic effects of the mycotoxin beauvericin to humans cell lines of myeloid origin. Pharmacol. Res. 49, 73-77

Chen, BF, Tsai, MC and Jow, GM., 2006. Induction of calcium influx from extracellular fluid by beauvericin in human leukemia cells. Biochem. Biophys. Res. Com. 340, 134-139.

347 Clarke, R., Connolly, L., Frizzell, C., Elliott, C.T., 2015. High content analysis: A sensitive tool to detect and quantify the cytotoxic, synergistic and antagonistic effects of chemical contaminants in food. Tox.Lett. 18, 278-86.

Collins, T.F., Shackelford, M.E., Sprando, R.L., Black, T.N., Láborde, J.B., Hansen, D.K., Eppley, M., Trucksess, M.W., Howard, P.C., Bryant, M.A., Ruggles, D.I., Olejnik, N and Rorie, J.I., 1998. Effects of Fumonisin B1 in Pregnant Rats. Food Chem. Toxicol. 36, 397-408.

Connolly, L., Ropstad, E., Verhaegen, S., 2011. In vitro bioassays for the study of endocrine-disrupting food additives and contaminants. Trends Anal. Chem. 30, 227238.

Deroche-Gamonet, V., Sillaber, I., Aouizerate, B., Izawa, R., Jaber, M., Ghozland, S., Kellendonk, C., Le Moal, M., Spanagel, R., Schütz, G., Tronche, F., Piazza, P.V., 2003. The glucocorticoid receptor as potential target to reduce cocaine abuse. J. Neurosci. 11, 4785-4790.

Dombrink-Kurtzman, M.A., 2003. Fumonisin and beauvericin induce apoptosis in turkey peripheral blood lymphocytes. Mycopathologia 4, 357-364

Dornetshuber, R., Heffeter, P., Lemmens-Gruber, R., Elbling, L., Marko, D., Micksche, M., Berger, W., 2009. Oxidative stress and DNA interactions are not involved in enniatin- and beauvericin-mediated apoptosisi induction. Molecular Nutrition and Food Research 53, 1112-1122.

EFSA (European Food Safety Authority)., 2005 Opinion of the Scientific Panel on

368 Contaminants in Food Chain on a request from the Commission related to fumonisins as undesirable substances in animal feed. EFSA, 10, 2005, p. 1004

EFSA (European Food Safety Authority). 2014 Scientific Opinion on the risks to human and animal health related to the presence of beauvericin and enniatins in food and feed. 
Fifty-sixth meeting of the Joint FAO/WHO Expert Committee on Food Additives. WHO Food Additives Series, No. 47; FAO Food and Nutrition Paper 74, 2001.

Ferrer, E., Juan-García, A., Font, G., Ruiz, M.J., 2009. Reactive oxygen species induced by beauvericin, patulin and zearalenone in CHO-K1 cells. Toxicol. In Vitro 1504-1509.

Frizzell, C., Ndossi, D., Verhaegen, S., Dahl, E., Eriksen, G., Sørlie, M., Ropstad, E.,Muller, M., Elliott, C.T., Connolly, L., 2011. Endocrine disrupting effects of zearalenone, alpha- and beta-zearalenol at the level of nuclear receptor binding and steroidogenesis. Toxicol. Lett. 206, 210-217.

Frizzell, C., Ndossi, D., Kalayou, S., Eriksen, G.S., Verhaegen, S., Sørlie, M., Elliott,C.T., Ropstad, E., Connolly, L., 2013a. An in vitro investigation of endocrine disrupting effects of the mycotoxin alternariol. Toxicol. Appl. Pharmacol. 271, 64-71.

Frizzell, C., Verhaegen, S., Ropstad, E., Elliott, C.T., Connolly, L., 2013b. Endocrine disrupting effects of ochratoxin $\mathrm{A}$ at the level of nuclear receptor activation and steroidogenesis. Toxicol. Lett. 217, 243-250.

Frizzell, C., Elliott, C. T., Connolly, L., 2014 Effects of the mycotoxin patulin at the level of nuclear receptor transcriptional activity and steroidogenesis in vitro. Tox. Lett. $229,366-373$

Fung Frederick and Clark Richard., 2004. Health effects of mycotoxins: A toxicological overview. J. Toxicol. 42, 217-234.

Gbore FA. 2009 Growth performance and puberty attainment in growing pigs fed dietary fumonisin B1. J Anim. Physiol. Anim. Nutr. 93, 761-7.

Gelderblom, W.C.A., Smuts, C.M., Abel, S., Snyman, S.D., Van Der Westhuizen, L., Huber, W.W., Swanevelder, S., 1997. Effect of Fumonisin B1 on the levels and fatty acid composition of selected lipids in rat liver in vivo. Food Chem. Toxicol. 35, 647656.

Harrison, L.R., Colvin, B.M., Green, J.T., Newman, L.E., Cole, J.R., 1990. Pulmonary oedema and hydrothorax in swine produced by fumonisin B1, a toxic metabolite of Fusarium moniliforme. J. Vet. Diagn. Invest. 2, 217-221

Honer, C., Nam, k., Fink, C., Marshall, P., Ksander, G., Chatelain, R.C., Cornell, W., Steele, R., Schweitzer, R., Schumacher, C., 2003. Glucocorticoid receptor antagonism by cyproterone acetate and RU486. Molecular Pharmacology. 63, 1012-1020.

Hussein, H. S.; Brasel, J. M., 2001. Toxicity, metabolism, and impact of mycotoxins on humans and animals. Toxicology 167, 101-134

International Programme on Chemical Safety, 2002. Global Assessment of the State-ofthe-Science of Endocrine Disruptors. World Health Organization, Geneva. http://www.who.int/ipcs/publications/ new_issues/endocrine_disruptors/en/. 
Jestoi M., 2008. Emerging Fusarium-mycotoxins fusaproliferin, beauvericin, enniatins, and moniliformin a review. Crit. Rev. Food. Sci. Nutr. 48, 21-49

Jestoi, M., Rokka, M., Peltonen, K., 2007. An integrated sample preparation to determine coccidiostats and emerging Fusarium- mycotoxins in various poultry tissues with LC MS/MS, Mol. Nutr. Food Res. 51, 625-637.

Jow, G.-M., Chou, C.-J., Chen, B.-F., Tsai, J.-H., 2004. Beauvericin induces cytotoxic effects in human acute lymphoblastic leukemia cells through cytochrome c release, caspase 3 activation: the causative role of calcium. Cancer Letters 216, 165-173

Kelce, W.R., Lambright, C.R., Gray, L.E., Jr., Roberts, K.P., 1997. Vinclozolin and p, $\mathrm{p}^{\prime}$-DDE after androgen-dependent gene expression: In vivo confirmation of an androgen receptor.mediated mechanism. Toxicol. Appl. Phamacol. 142, 192-200.

Kelce, W.R., Stone, C.R., Laws, S.C., Gray, L.E., Jr, Kemppainen, J.A., Wilson, E.M., 1995. Persistent DDT metabolite p, $\mathrm{p}^{\prime}-\mathrm{DDE}$ is apotent androfen receptor antagonist. Nature. 375, 581-585.

Kellerman, T.S., Mararas, W.I.-O., Thiel, G., Gelderblom, W.C.A., Cawood, M., Coetzer, J.A.W., 1990. Leukoencephalomalacia in two horses induced by oral dosing of fumonisin B1. J. Vet. Res. 57, 269-275

Liu, Z., Auboeuf, D., Wong, J., Chen, JD., Tsai, SY., Tsai, MJ., O’Malley, B.W., 2002. Coactivator/corepressor ratios modulate PR-mediated transcription by the selective receptor modulator RU486. Proc. Natl. Acad. Sci. 99, 7940-4

Mallebrera B, Font G and Ruiz M J., 2014. Disturbance of antioxidant capacity produced by beauvericin in CHO-K1 cells. Toxicol. Lett. 226, 337-342.

Martins, F.A., Dias Ferreira, F.M., Dias Ferreira, F., Bando, É. Nerilo, S.B., Hirooka, E.Y., Machinski Jr. M., 2012. Daily intake estimates of fumonisins in corn-based food products in the population of Parana, Brazil. Food Control. 23, 614-618.

Meca, G., Fernández-Franzón, M., Ritieni, A., Font, G., Ruiz, M.J., Mañes, J., 2010. Formation of Fumonisin B1-Glucose reaction product, in vitro cytotoxicity, and lipid peroxidation on kidney cells. J. Agric. Food Chem. 58, 1359-1365.

Merrill, A.H., Sullards, M.C., Wang, E., Voss, K.A., Riley, R.T., 2001. Sphingolipid metabolism: roles in signal transduction and disruption by fumonisins. Environ. Health Perspect. 109, 283-289.

Neulen J , Williams RF, Breckwoldt M, Chwalisz K, Baulieu EE, Hodgen GD., 1996. Non-competitive anti-oestrogenic actions of progesterone antagonists in primate endometrium: enhancement of oestrogen and progesterone receptors with blockade of postreceptor proliferative mechanisms. Hum Reprod. 11, 1533-7. 
Prosperini A, Meca, G, Font G and Ruiz M J., 2012. Study of the cytotoxic activity of beauvericin and fusaproliferin and bioavailability in vitro on Caco-2 cells. Food. Chem. Toxicol. 50, 2356-2361

Prosperini A, Juan-García A, Font G and Ruiz M J., 2013. Beauvericin-induced cytotoxicity via ROS production and mitochondrial damage in Caco-2 cells. Toxicol. Lett. 222, 204-211.

Ramirez CN, Antczak C, Djaballah H., 2010. Cell viability assessment: toward contentrich platforms. Expert Opin. Drug Discov. 5, 223-233.

Sambuy, Y., De Angelis, I., Ranaldi, G., Scarino, M.L., Stammati, A., Zucco, F., 2005. The Caco-2 cell line as a model of the intestinal barrier: influence of cell and culturerelated factor son Caco-2 cell functional characteristics. Cell Biol. Toxicol. 21, 1-26.

Savory, J.G.A., Préfontaine, G.G., Lamprecgt, C., Liao, M., Walther, R.F., Lefebvre, 457 Y.A., Haché, R.J.G., 2001. Glucocorticoid receptor homodimers and Glucocorticoid458 Mineralcorticoid receptor heterodimers form in the cytoplasm through alternative dimerization interfaces. Mol. Cell. Biol. 21, 781-793

Serrano AG, Font G, Ruiz MJ and Ferrer E., 2012. Co-occurrence and risk assessment of mycotoxins in food and diet from Mediterranean area. Food Chem. 135, 423-429.

Spitz, I.V., 2003. Progesterone antagonists and progesterone receptor modulator: an overview. Steroids, 68, 981-993

Tolosa J, Font G, Mañes J and Ferrer E., 2013. Nuts and dried fruits: natural occurrence of emerging Fusarium mycotoxins. Food Control, 33, 215-220.

Tolosa, L., Gómez-Lechón, M.J., Donato, M.T., 2015. High- content screening techonology for studying drug-induced hepatotoxicity in cell models. Arch.Toxicol. In press.DOI 10.1007/s00204-015-1503-z

Tonshin, A.A., Teplova, V.V., Andersson, M.A., Salkinoja-Salonen, M.S., 2010. The 470 Fusarium mycotoxins enniatins and beauvericin cause mitochondrial dysfunction by 471 affecting the mitochondrial volume regulation, oxidative phosphorylation and ion homeostasis. Toxicology 276, 49-57.

473 Wan, L.Y.M., Turner, P.C., El-Nezami, H., 2013. Individual and combined cytotoxic 474 effects of Fusarium toxins (deoxynivalenol, nivalenol, zearalenone and fumonisins B1) on swine jejunal epithelial cells. Foof and Chem. Tox. 57, 276-283.

476 Willemsen, P., Scippo, M., Kausel, G., Figueroa, J., Maghuin-Rogister, G., Martial, J., 477 2004. Use of reporter cell lines for detection of endocrine-disrupter activity. Anal. 478 Bioanal. Chem. 378, 655-663. 
479 Wilson, V.S., Bobseine, K., Lambright, C.R., L.E.Gray, Jr. 2002. A novel Cell line, 480 MDA-kb2 that stably express an androgren and glucocorticoid responsive reporter for 481 the detection of hormone receptor agonists and antagonists. Toxicol.Sci. 60, 69-81 


\section{Legends of Figures:}

486 Fig.1 Viability of the RGA cell lines a) MMV-Luc b) TARM-Luc c) TM-Luc and d) 487 TGRM-Luc following exposure to 0.001-10 $\mu \mathrm{M}$ of FB1 and BEA for $48 \mathrm{~h}$ and 488 compared to the solvent control, as determined in the MTT assay. Values are means \pm 489 SEM for the three separate experiments $(\mathrm{n}=3), p \leq 0.001(* * *)$.

490

491 Fig.2 Results of RGA antagonistic test following co-exposure of the positive control 492 with FB1 (0.001-10 $\mu \mathrm{M})$ in the a) MMV-Luc (oestrogen responsive), b) TARM-Luc 493 (androgen responsive), c) TM-Luc (progestagen responsive) and d) TGRM-Luc 494 (glucocorticoid responsive) RGA cells. Responses measured are compared to the 495 solvent and the positive control $(1.36 \mathrm{ng} / \mathrm{ml} 17 \beta$-estradiol, $14.5 \mathrm{ng} / \mathrm{ml}$ testosterone, 157

496

497 498

499

500

501

502

503

504

505

506

507

508

509

510

511

512

513

514

515 $\mathrm{ng} / \mathrm{ml}$ progesterone and $181 \mathrm{ng} / \mathrm{ml}$ cortisol, respectively). Results are expressed as the mean percentage response \pm SEM for the three separate experiments $(n=3), p \leq 0.05(*)$.

Fig.3 Results of RGA antagonistic test following co-exposure of the positive control with BEA (0.001-10 $\mu \mathrm{M})$ in the a) MMV-Luc (estrogen responsive), b) TARM-Luc (androgen responsive), c) TM-Luc (progestagen responsive) and d) TGRM-Luc (glucocorticoid responsive) RGA cells. Responses measured are compared to the solvent and relevant positive controls $(1.36 \mathrm{ng} / \mathrm{ml} 17 \quad \beta$-estradiol, $14.5 \mathrm{ng} / \mathrm{ml}$ testosterone, $157 \mathrm{ng} / \mathrm{ml}$ progesterone and $181 \mathrm{ng} / \mathrm{ml}$ cortisol, respectively). Responses are expressed as the mean percentage response \pm SEM for the three separate experiments $(\mathrm{n}=3), p \leq 0.05(*), \leq 0.01(* *), \leq 0.001(* * *)$.

Fig.4 Quantification of the cytotoxic effects of $0.001-1 \mu \mathrm{M}$ BEA in the progestagen responsive TM-Luc cells as measured by HCA. a) cell number (CN) b) nuclear area (NA), c) nuclear intensity (NI), d) plasma membrane permeability (PMP), e) mitochondrial membrane potential (MMP) and f) mitochondrial mass (MM). Data are expressed as mean values \pm SEM for the three separate experiments $(n=3) . p \leq 0.05\left(^{*}\right)$ and $p \leq 0.01(* *)$ indicate significant differences from the solvent control.

Fig.5 Quantification of the cytotoxic effects of $0.001-10 \mu \mathrm{M} F B 1$ and BEA in the gut 
516 derived Caco-2 cells after $48 \mathrm{~h}$ exposure as measured by HCA. a) cell number (CN) b)

517 nuclear area (NA), c) nuclear intensity (NI), d) plasma membrane permeability (PMP),

518 e) mitochondrial membrane potential (MMP) and f) mitochondrial mass (MM). Data are

519 expressed as mean values \pm SEM for the three separate experiments $(n=3) . p \leq 0.001$

$520(* * *)$ indicate significant differences from the solvent control.

521

522 
Fig.1

a)

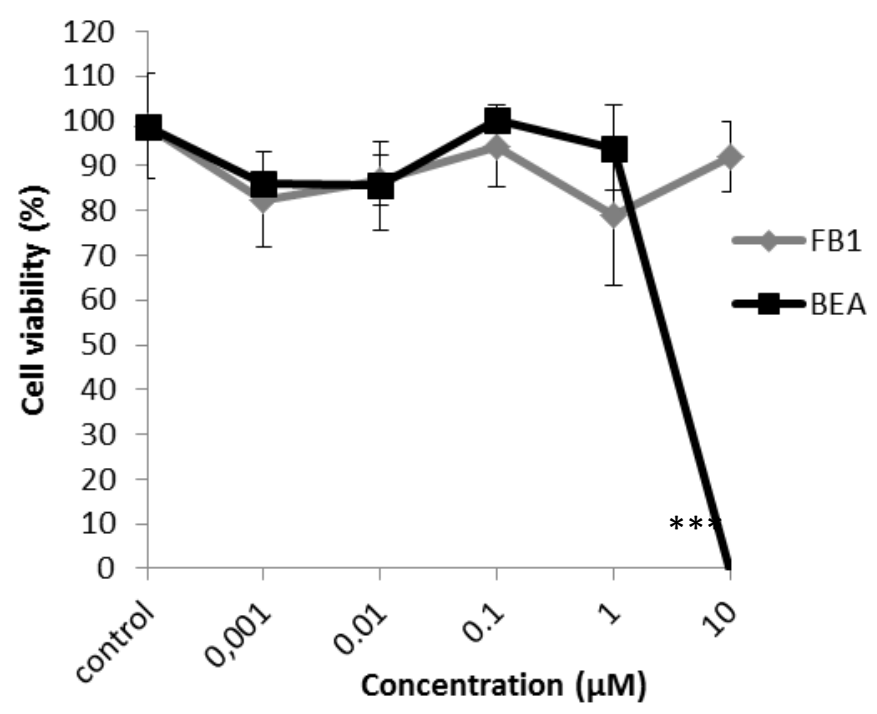

c)

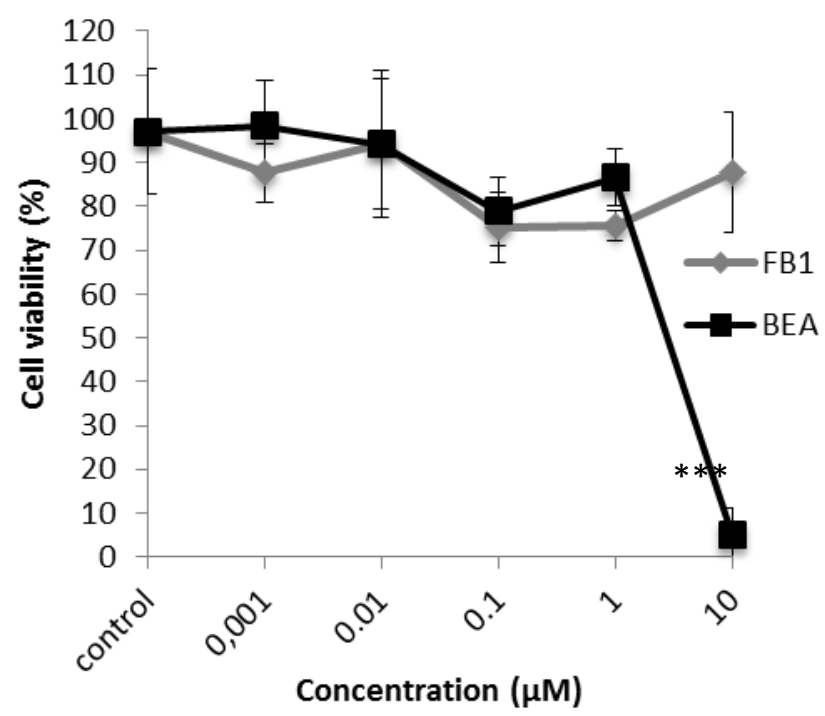

b)

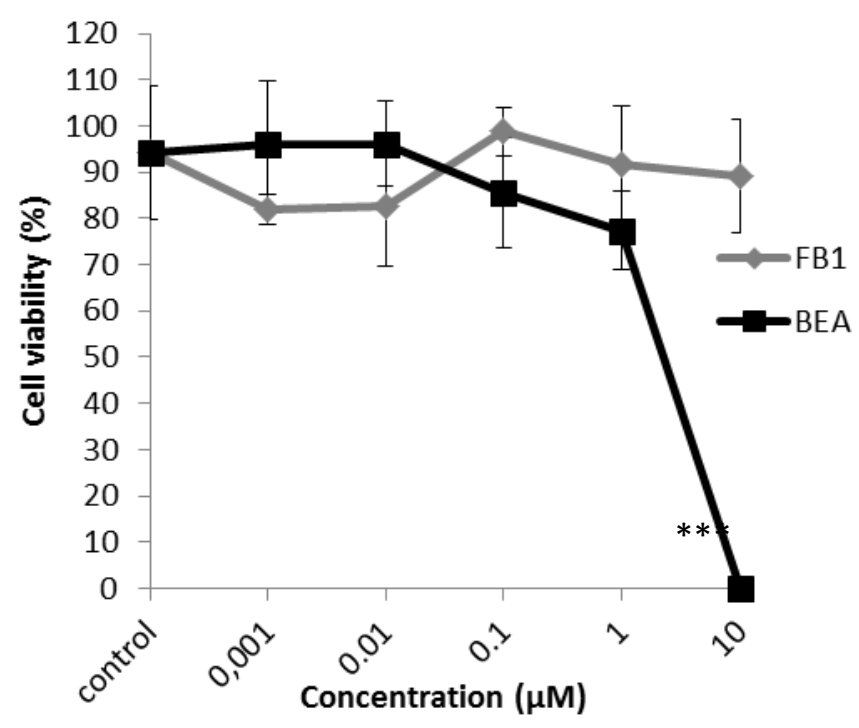

d)

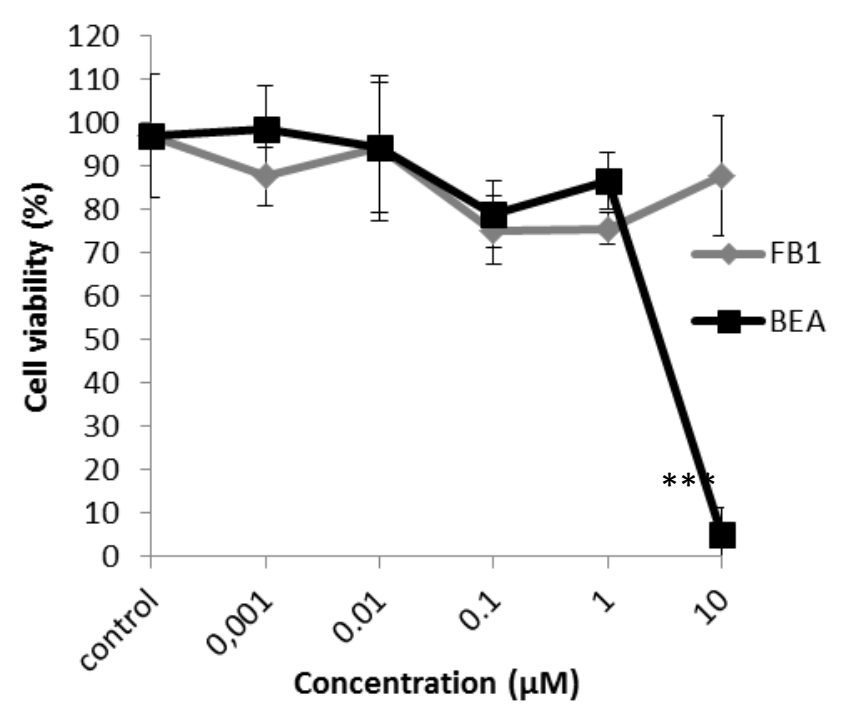


a)

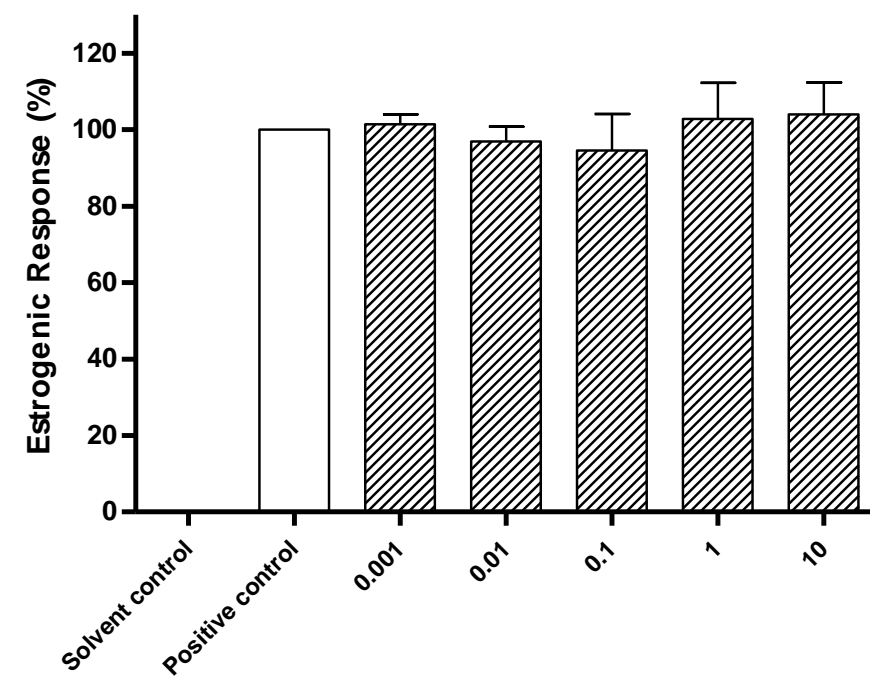

FB1 $(\mu M)$

c)

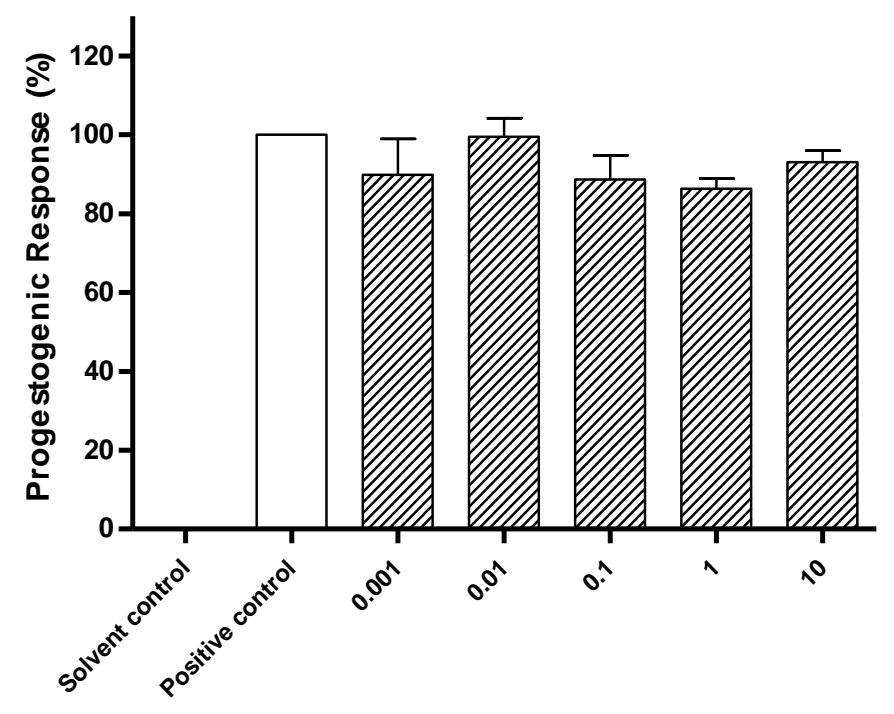

FB1 ( $\mu M)$ b)

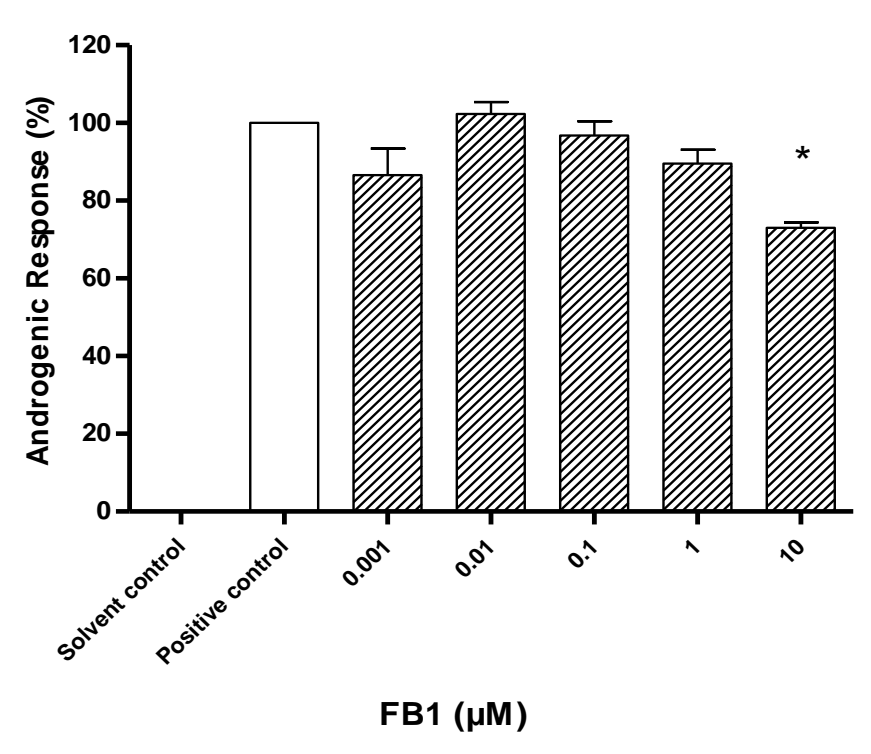

d)

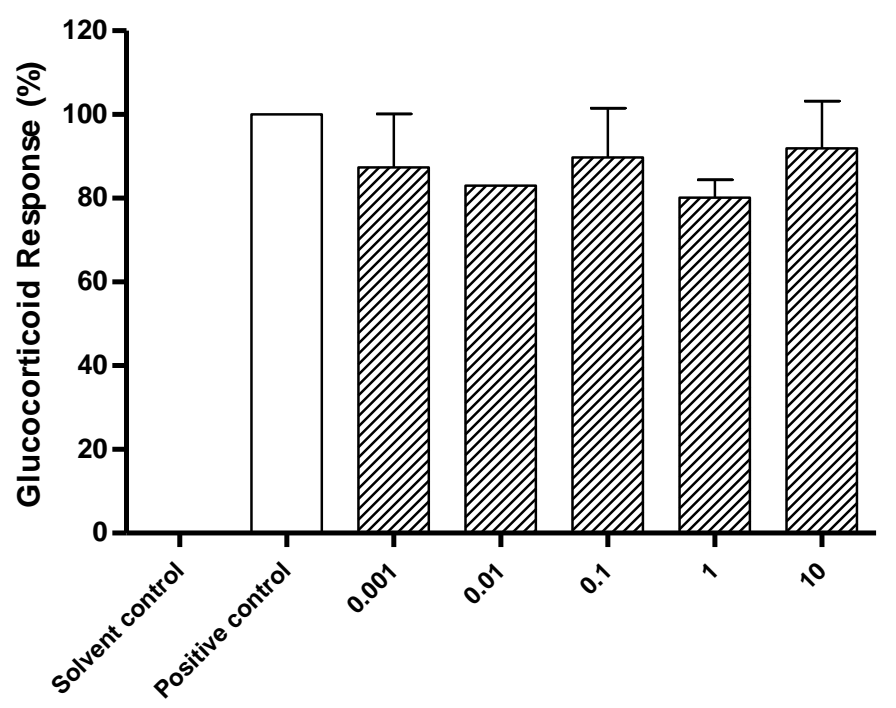

FB1 $(\mu M)$ 
a)

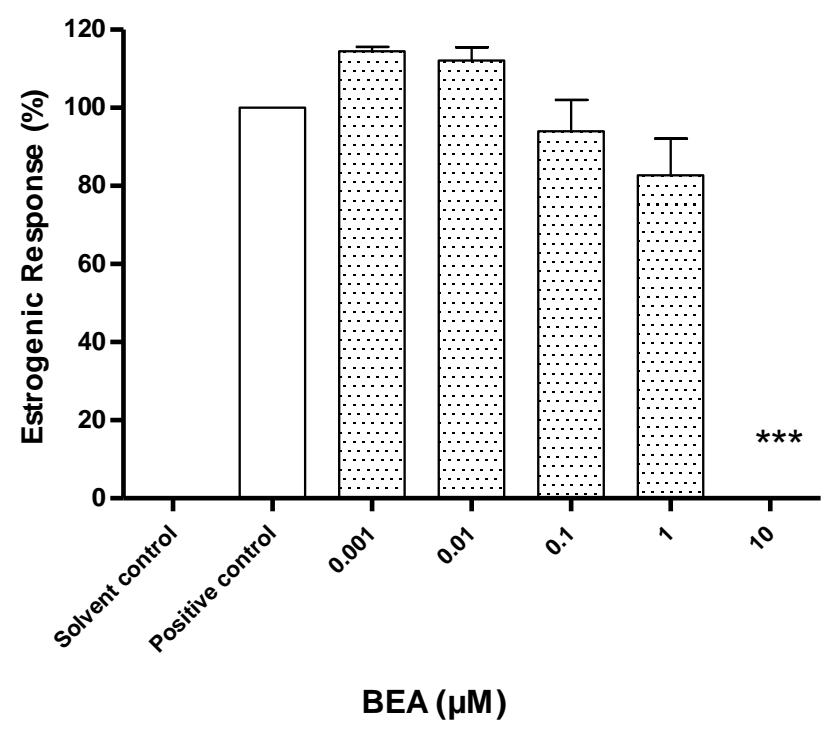

c)

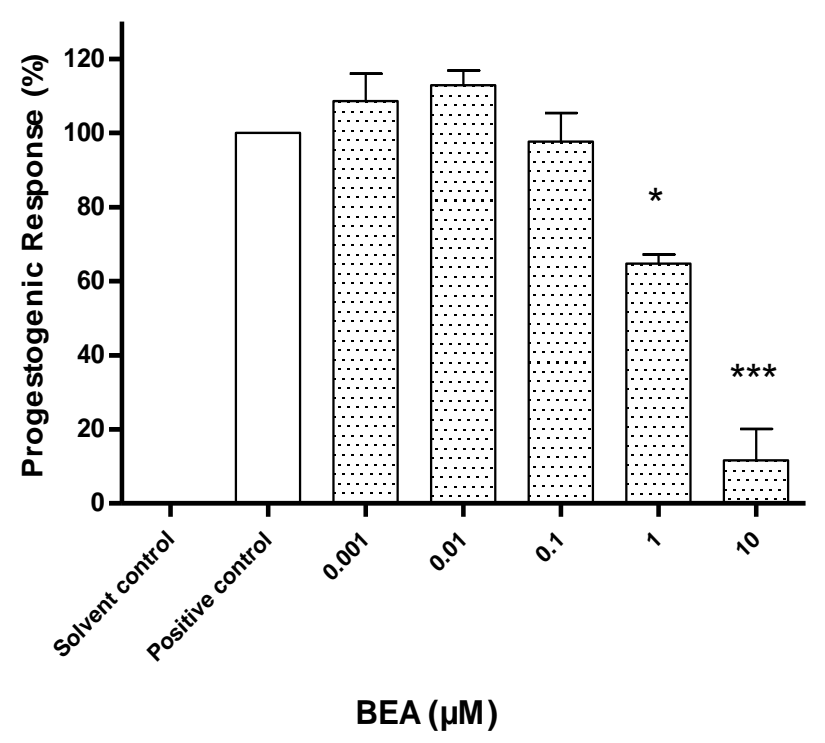

b)

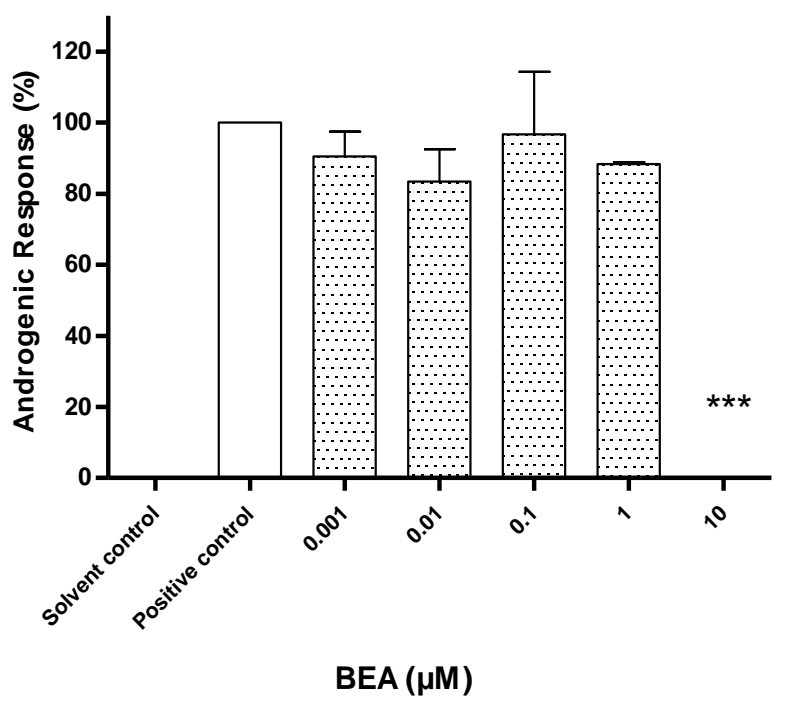

d)

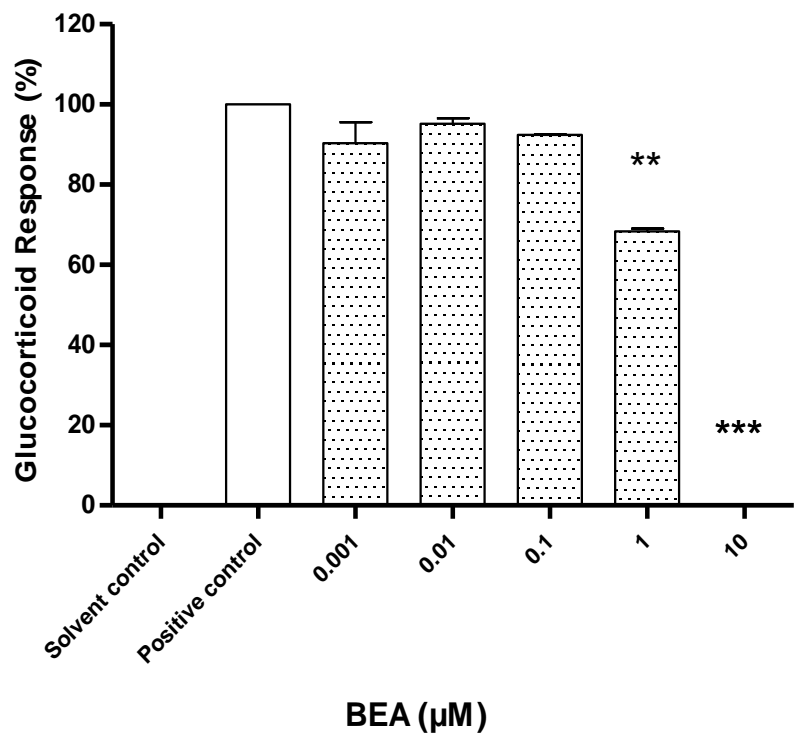


Fig. 4

a)

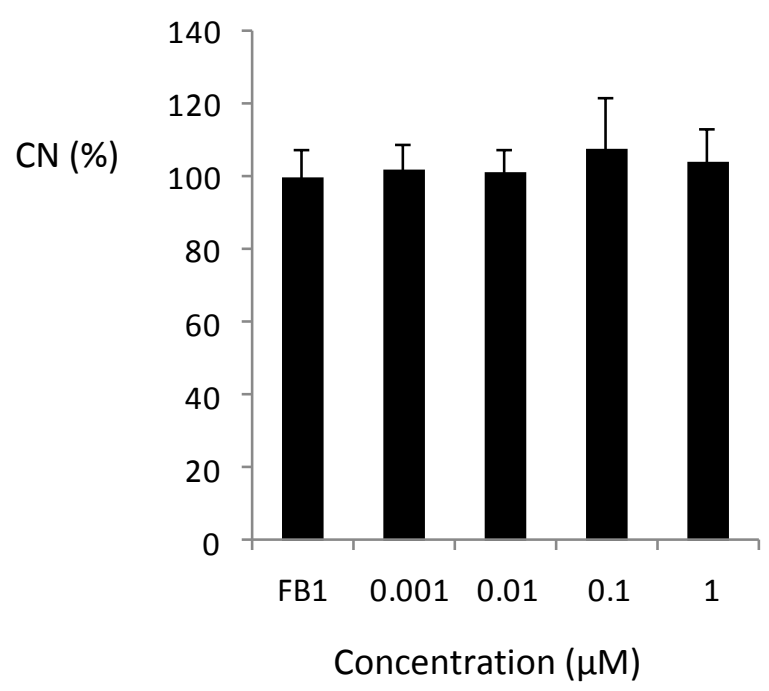

c)

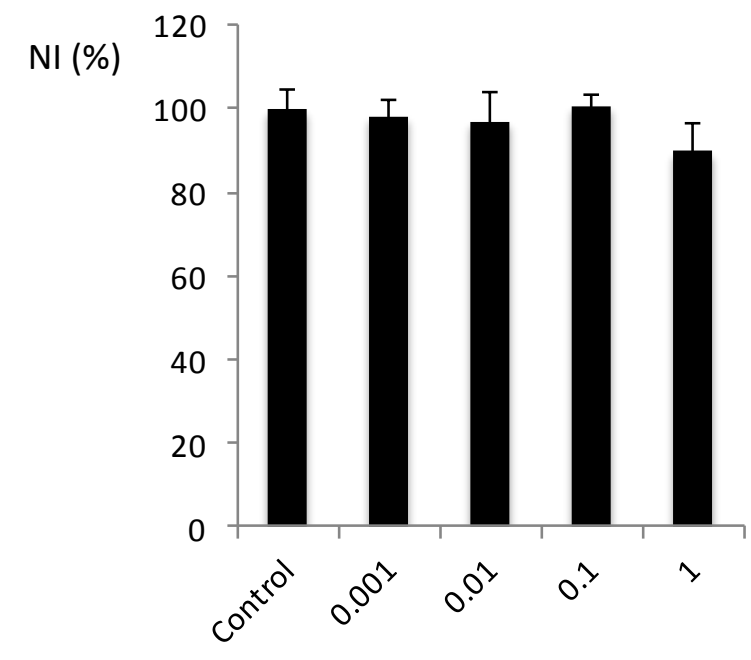

Concentration ( $\mu \mathrm{M})$

e)

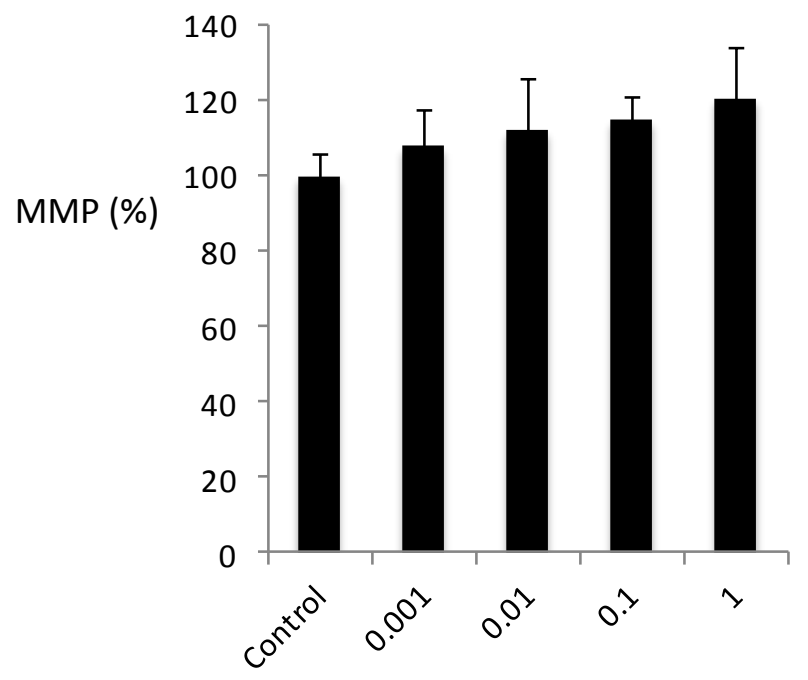

Concentration ( $\mu \mathrm{M})$ b)

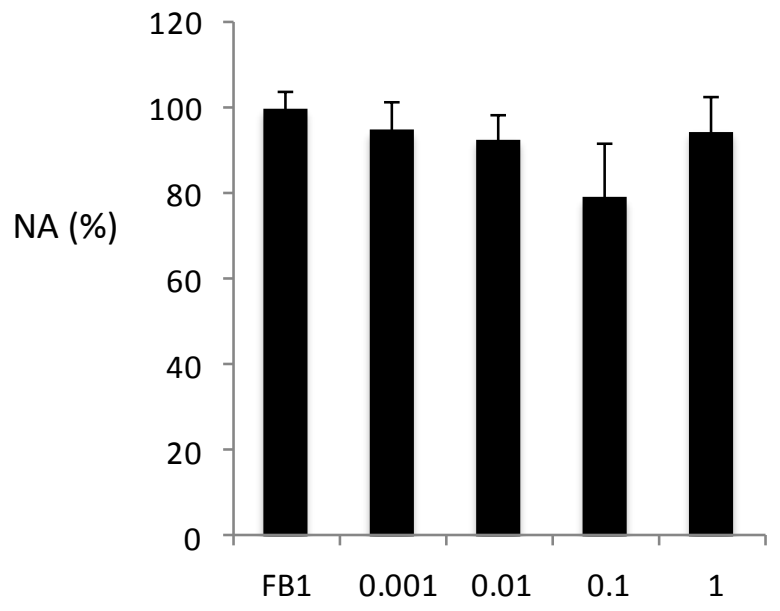

Concentration ( $\mu \mathrm{M})$

d)

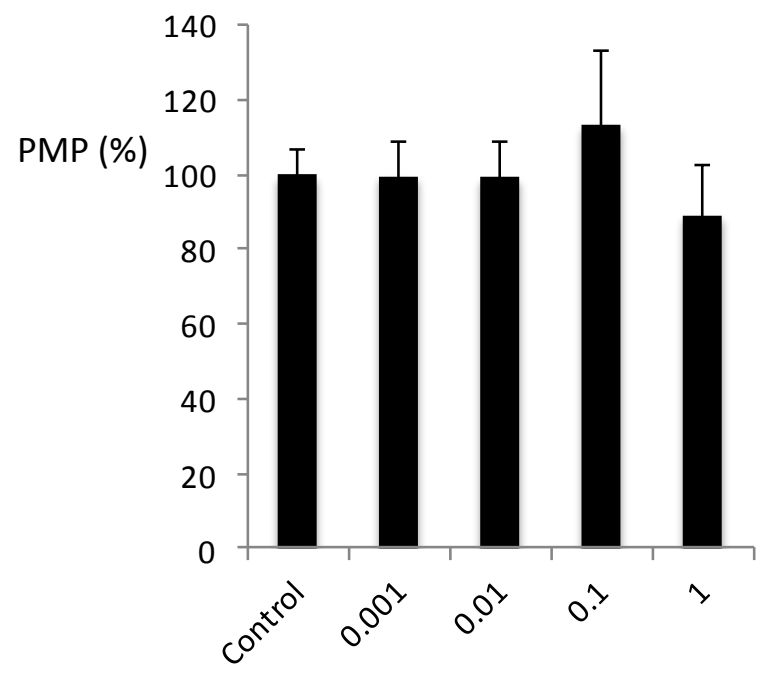

Concentration $(\mu \mathrm{M})$

f)

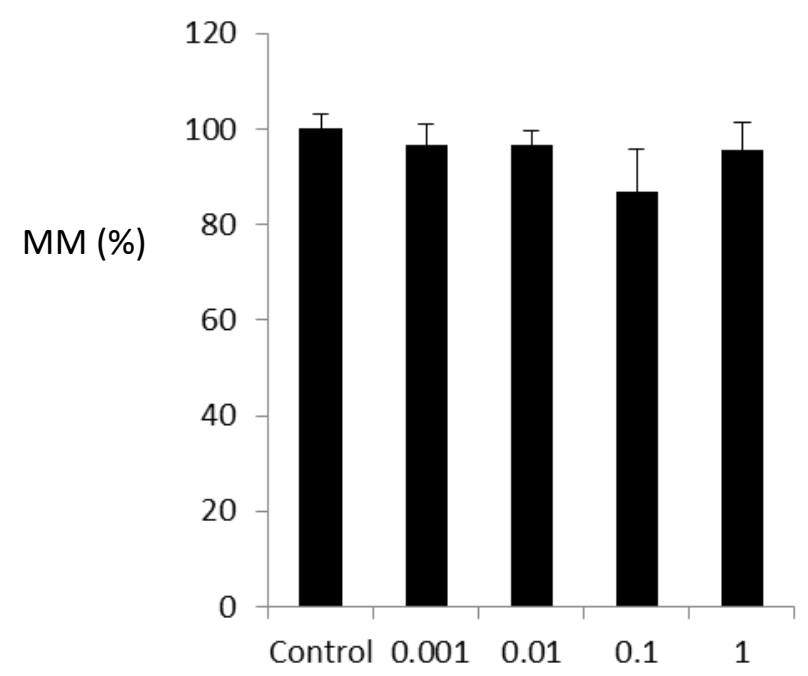

Concentration ( $\mu \mathrm{M})$ 
Fig. 5.
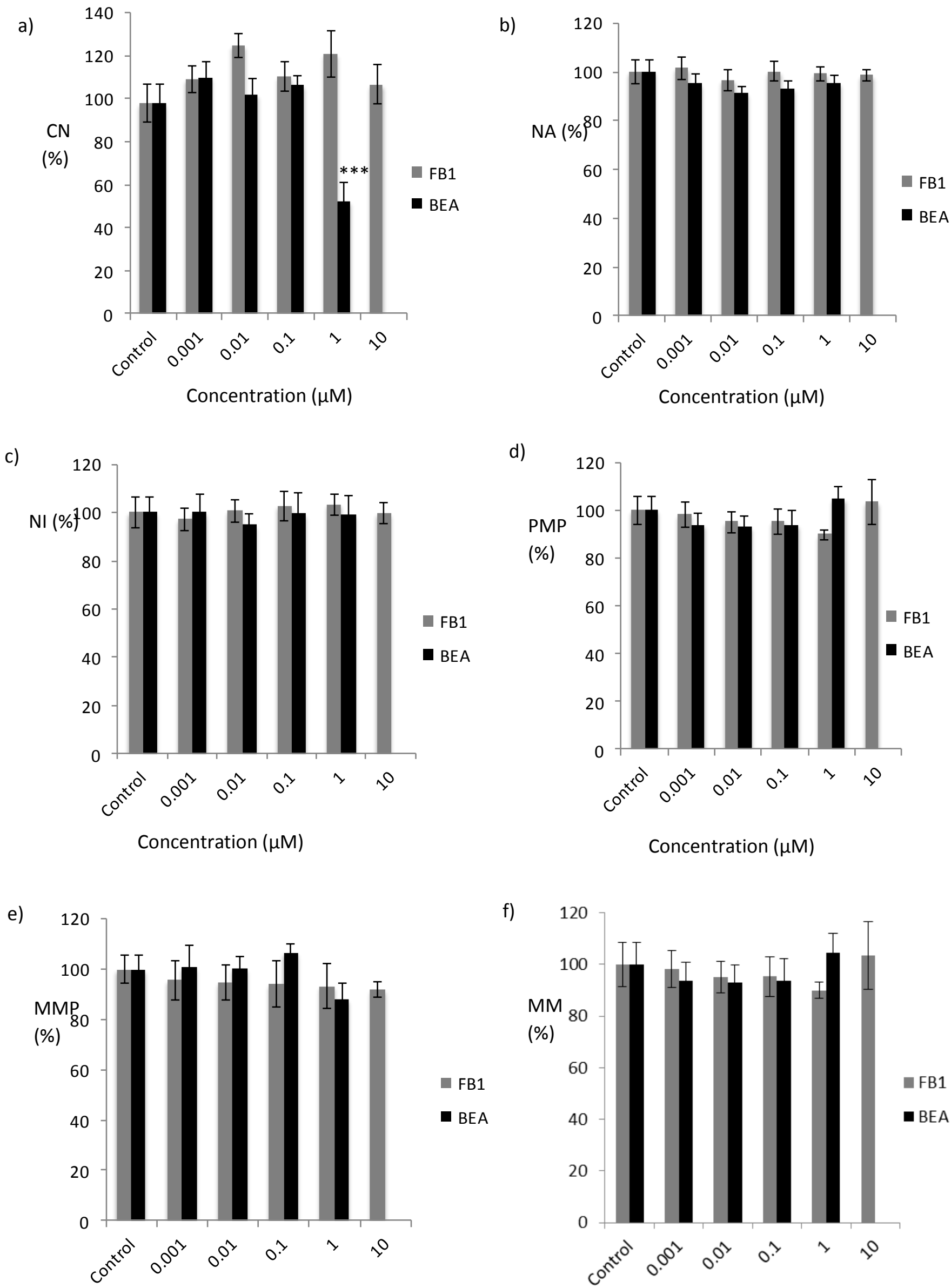

Concentration ( $\mu \mathrm{M})$

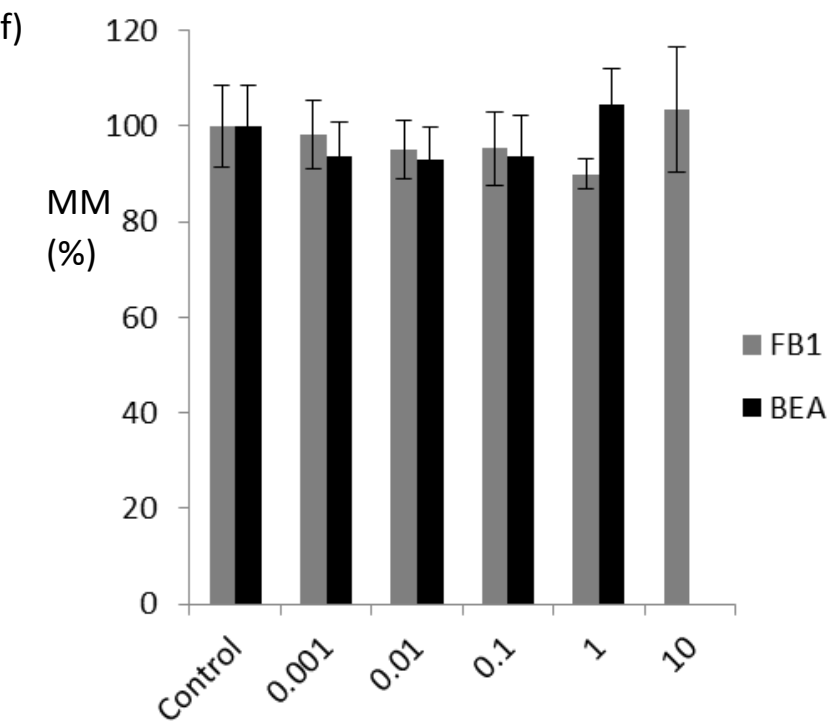

Concentration $(\mu \mathrm{M})$ 